\title{
Genetic diversity of Rhizophora mucronata in eastern region of Timor Island, Indonesia as revealed by RAPD
}

\author{
IHWAN $^{1}$, USLAN $^{1}$, WIDODO $^{2, \boldsymbol{v}}$, LUCHMAN HAKIM $^{2}$ \\ ${ }^{1}$ Department of Biology, Faculty of Teacher Training and Education, Universitas Muhammadiyah Kupang. Jl. K.H. Ahmad Dahlan, Kayu Putih, Oebobo, \\ Kupang City 85228, East Nusa Tenggara, Indonesia \\ ${ }^{2}$ Department of Biology, Faculty of Mathematics and Natural Sciences, Universitas Brawijaya. Jl. Veteran, Malang 65145, Malang, East Java, Indonesia. \\ Tel.: +62-341-575841, `email: widodo@ub.ac.id, dodot134@gmail.com
}

Manuscript received: 8 May 2019. Revision accepted: 29 October 2019.

\begin{abstract}
Ihwan, Uslan, Widodo, Hakim L. 2019. Genetic diversity of Rhizophora mucronata in eastern region of Timor Island, Indonesia as revealed by RAPD. Biodiversitas 20: 3364-3371. Mangrove ecosystems have essential functions in producing organic materials, protecting against erosion, and supporting the area between land and sea. Rhizophora mucronata is a dominant mangrove species in all coastal areas of Timor Island, East Nusa Tenggara, Indonesia. Recent reports suggest that mangroves have been affected by anthropogenic pressure and natural disasters. The aim of this study was to determine the genetic diversity of $R$. mucronata in the east region of Timor Island. This study is important in supporting mangrove protected management planning in the region. The sampling was carried out in six mangrove vegetation sites, DNA was isolated from the leaves and used for PCR-RAPD using six primers. Dendrogram analysis of the species was determined based on UPGMA (unweighted pair group method) and the similarity coefficient from Nei and Li using the MVSP program. The results showed that the six primers used generated a DNA length of 270-1345 bp, with the number of bands being 22-27. The percentage of polymorphism ranged from $73.91 \%$ to $86.96 \%$ in all primers used, with a polymorphic information content (PIC) value of 0.94 . Thus, it can be concluded that the value of genetic diversity (He) from the R. mucronata mangrove population in Timor Island has a value of 0.666 . The $R$. mucronata population in Abudenok and Tanjung Bastian has the highest genetic diversity with a value of 0.667 , while the population in Tanjung Tuamese has the lowest genetic diversity with a value of 0.664. Based on the results of the dendrogram analysis, the $R$. mucronata population in Timor Island correlated with its geographical location. The adjacent populations have a tendency to form one subgroup.
\end{abstract}

Keywords: Genetic diversity, mangrove, Rhizophora mucronata, Timor Island

\section{INTRODUCTION}

Mangroves are coastal ecosystems that filter nutrients, produce organic materials, serve as wave-current dampers, and protect against erosion, among several other functions (Manurung et al. 2017). Mangrove ecosystems can grow well in intertidal zones along the coastline (Lira-Medeiros et al. 2015), such as the coastal areas of Timor Island. Based on previous research, Rhizophora mucronata is abundant in all coastal areas of Timor Island, East Nusa Tenggara. Mangrove forests in East Nusa Tenggara cover a total area of about 1930 ha (Darsidi 1984). However, mangroves in the area have been changed for many purposes, such as for settlement, industry, recreation (Bessie et al. 2013; Matatula et al. 2019), and fish ponds (Hidyatullah and Umroni 2013). Anthropogenic activity and natural disasters (Romanach et al. 2018) have been detrimental to mangrove conditions. Therefore, intensive study of species diversity is important to support mangrove protection management planning in the region. Hence, this study was undertaken to assess the genetic diversity of $R$. mucronata in the coastal area of the eastern region of Timor Island. This study complements the taxonomical studies of $R$. mucronata based on morphological characteristics using vegetative and generative organs.
The study of genetic variation of $R$. mucronata is very important for providing information on species fitness in the ecosystem. Moreover, genetic diversity also contributes to a population's adaptability to changes in the environment (Arif et al. 2010). Various techniques are used to assess genetic diversity, such as morphological characteristics, allozymes, and molecular markers (Govindaraj et al. 2015). However, DNA-based molecular markers are considered stable and little influenced by environmental changes (Sudheer et al. 2010).

DNA-based molecular markers commonly used to assess genetic diversity in plants include restriction fragment length polymorphism, random amplified polymorphic DNA (RAPD), simple sequence repeats, amplified fragment length polymorphism (Mondini et al. 2009), and a new class of advanced techniques using nextgeneration sequencing (Onda and Mochida 2016). These techniques are well established, and their advantages and limitations have been explored (Govindaraj et al. 2015). An older technique that is still relevant and can be used to assess genetic diversity in plants is RAPD. RAPD is a DNA-based method that has been widely used for a variety of purposes, such as genetic diversity (Manurung et al. 2017), cultivar identification (Al-Khalifah and Shanavaskhan 2017), and conservation strategies (Hazarika et al. 2013). RAPD is still reliable in assessing genetic 
diversity in Durio zibethinus (Sundari et al. 2017), Citrullus colocynthis (Verma et al. 2017), macrofungi (Sandhya et al. 2018), and Avicennia (Hazarika et al. 2013). RAPD has several advantages compared to other techniques, such as simplicity of technique, only requiring a small amount of DNA template, and not requiring initial genome information (Kiran et al. 2015; Nair and Resmi 2016).

Most taxonomical studies of $R$. mucronata are only based on morphological characteristics using vegetative and generative organs. Hence, this study was undertaken to assess genetic diversity among $R$. mucronata in the coastal area of the eastern region of Timor Island based on RAPD DNA markers.

\section{MATERIALS AND METHODS}

\section{Time and research location}

The study was carried out for five months, from March to July of 2018. Sampling was carried out in six locations in the eastern region of Timor Island, namely Humusu, Tanjung Bastian, Oemanu, and Tanjung Tuamese, in Timor Tengah Utara District as well as Kletek and Abudenok in Malaka District of East Nusa Tenggara Province, Indonesia (Figure 1). Laboratory analysis was conducted in the Plant Physiology Laboratory, Tissue Culture Laboratory, Micro Technical Laboratory, and Cell Biology and Molecular Laboratory of the University of Brawijaya, Malang, Indonesia and the Biology Laboratory of Muhammadiyah University of Kupang, Indonesia.

\section{Sampling technique}

Young leaves of $R$. mucronata were collected in six selected sites in the coastal area of the Timor Island (Figure 1). At each site, 3 samples were selected for DNA extraction. The coordinates of each selected $R$. mucronata were marked using GPS. Fresh young leaves were collected, put into a plastic bag containing silica gel, and labeled.

\section{DNA isolation}

DNA was isolated based on the CTAB (Cetyltrimethylammonium Bromide) method. A total of $0.1 \mathrm{~g}$ of young leaves were ground to powder by mortar and pestle. The powdered tissue was added to $1 \mathrm{~mL}$ extraction buffer $(2 \%$ CTAB, $1.4 \mathrm{M} \mathrm{NaCl}, 0.2 \% \quad \beta$ mercaptoethanol, $50 \mathrm{mM} \mathrm{Na}{ }_{2}$ EDTA [pH 8.0] and $100 \mathrm{mM}$ Tris- $\mathrm{HCl}[\mathrm{pH} 8.0])$ and incubated at $65^{\circ} \mathrm{C}$ using a water bath for 60 minutes. The sample was turned every 10 minutes, then $700 \mu \mathrm{L}$ of chloroform: isoamyl alcohol (24: 1) was added into suspension and homogenized using a vortex. The suspension was centrifuged at $12.000 \mathrm{rpm}$ for 5 minutes at room temperature. The supernatant was transferred into a new tube, and an equal volume of cold ethanol was added to the obtained supernatant to create a 1: 1 mixture. The suspension was mixed and incubated for 1 hour at $-20^{\circ} \mathrm{C}$, the suspension was centrifuged at 12.000 rpm for 3 minutes. The pellets then were washed with 400 $\mu \mathrm{L} 70 \%$ alcohol. Pellets were dried, and $100 \mu \mathrm{L}$ of sterile $\mathrm{ddH}_{2} \mathrm{O}$ was added (Uslan and Pharmawati 2015).

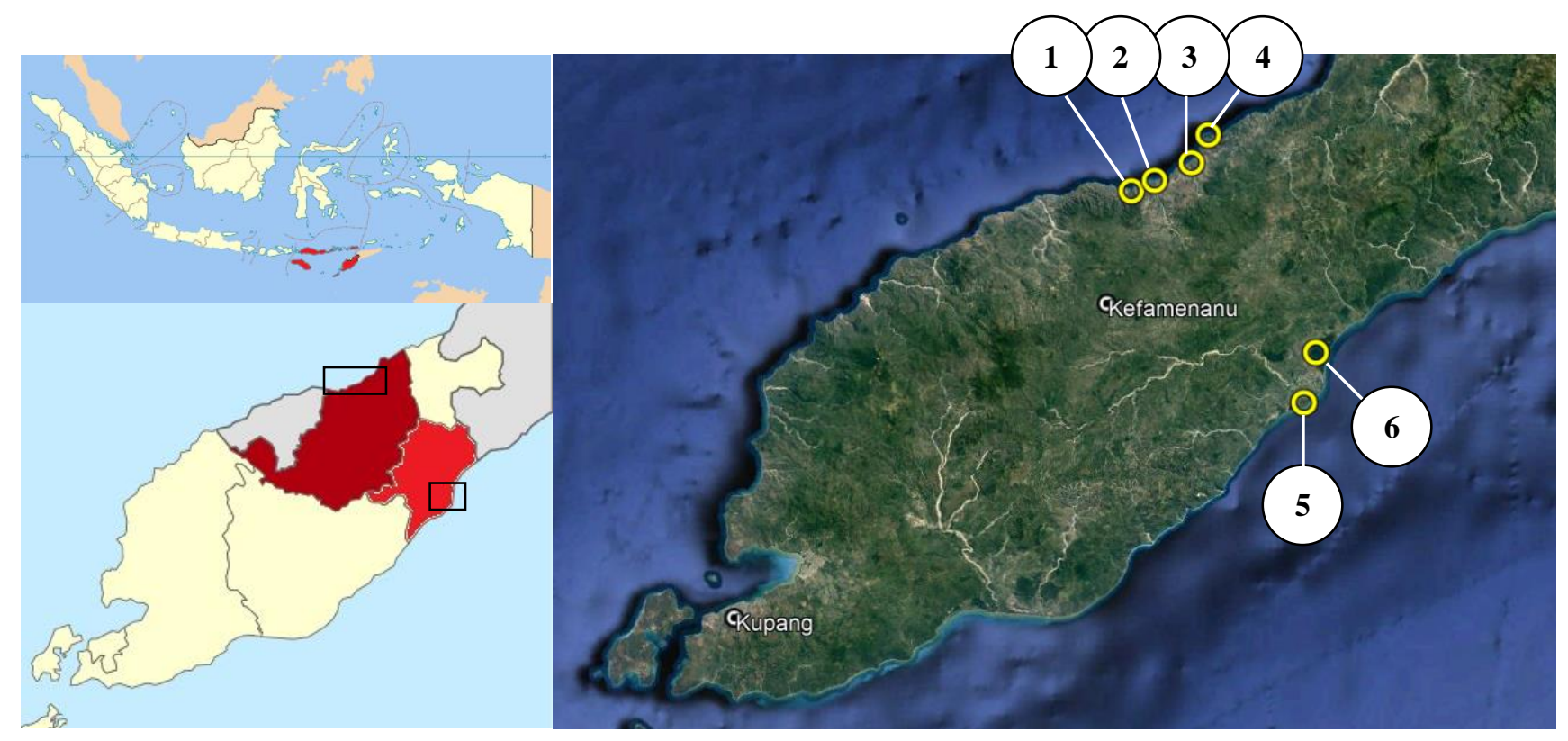

Figure 1. Map of sampling locations in districts of Timor Tengah Utara and Malaka, East Nusa Tenggara Province, Indonesia. $R$. mucronata leaves were taken from 6 places, i.e.: 1. Humusu, 2. Tanjung Bastian, 3. Oemanu, 4. Tanjung Tuamese, 5 . Kletek, and 6. Abudenok 


\section{DNA quantification}

The quality of the DNA was checked in $1 \%$ agarose gel with $1 \mathrm{x}$ TAE buffer (40 $\mathrm{mM}$ Tris-acetate $[\mathrm{pH}$ 7.9] and 2 $\mathrm{mM} \mathrm{Na} \mathrm{N}_{2} \mathrm{EDTA}$ ). A total of $3 \mu \mathrm{L}$ of the sample was mixed with loading dye and put into the wells. Lambda DNA with concentrations of $100 \mathrm{ng}, 200 \mathrm{ng}$, and $300 \mathrm{ng}$ was inserted into the wells to estimate DNA concentration. Electrophoresis was carried out at $100 \mathrm{~V}$ for 30 minutes. DNA staining was done by soaking the gel in Ethidium Bromide for 30 minutes (Sambrook and Russell 2001), and DNA visualization was carried out with a GelDoc UV Transilluminator.

\section{RAPD analysis}

RAPD analysis was performed using 6 primers (Table 1) for the amplification process in PCR. Amplifications were performed in $25 \mu \mathrm{L}$ reaction volume containing 0.2 $\mathrm{mM}$ dNTPs, $3 \mathrm{mM} \mathrm{MgCl} 2,1 \mathrm{U}$ Taq DNA Polymerase, $1 \mathrm{x}$ polymerase buffer, $1.9 \mu \mathrm{M}$ primer, $50 \mathrm{ng}$ DNA, and sterile water. Amplification was performed in a thermocycler for 44 cycles with the following parameters: pre-denaturation at $94^{\circ} \mathrm{C}$ for 5 minutes, followed by denaturation at $94^{\circ} \mathrm{C}$ for 1 minute, annealing at $30^{\circ} \mathrm{C}$ for 1 minute, and elongation at $72^{\circ} \mathrm{C}$ for 2 minutes. The final extension was carried out at $72^{\circ} \mathrm{C}$ for 8 minutes (Sahao et al. 2007). The amplified product was checked using $1.8 \%$ agarose gel electrophoresis.

\section{Data scoring and analysis}

The size of the DNA band obtained was determined by plotting on semi-log paper. The migration distance from the gel well was measured to the middle of each ladder band of $100 \mathrm{bp}$. The distance from the well to the midladder band was plotted on the X-axis, and the DNA size on the ladder was plotted on the Y-axis. The points on the semi-log paper were linked to create a standard curve. The migration distance was measured from the PCR product obtained and plotted on a standard curve to determine its size.

DNA bands of known size were scored. The banding patterns obtained from RAPD were scored as present (1) or absent (0). Subsequently, clustering analysis was carried out using the UPGMA method based on the similarity coefficient from Nei and Li using MVSP 3.2 software. To determine the level of primary informativeness, the polymorphic information content (PIC), effective multiplex ratio (EMR), and marker index (MI) were calculated (Weir 1990).

PIC Value for each primer was calculated with Equation: $\mathrm{PICi}=2 \mathrm{fi} \quad(1-\mathrm{fi})$; PIC_i: polymorphism information content of the primer $i$, fi: frequency of primer fragment that was present, (1-f_i $)$ : frequency of primer fragment that was absent. EMR was calculated by using Equation: $E M R=\eta \times \beta$; where $\eta$ is the total number of fragments per primer and $\beta$ is the fraction of polymorphic fragments (Laurentin and Karlovsky 2007). MI was calculated with Equation 3 (Varshney et al. 2007):

$$
\mathrm{MI}=\mathrm{PIC} \times \mathrm{EMR}
$$

Genetic diversity was determined based on

Total Effective Allele $\left(\mathrm{n}_{\mathrm{a}}\right)$

$$
n_{e}=\frac{\sum \text { Allel }}{\sum \text { Locus }}
$$

Total Observed Allele $\left(n_{e}\right)$

$$
n_{e}=\frac{\sum \text { Allel }}{\sum \text { Locus }} \text {; }
$$

Genetic Diversity $\left(H_{e}\right)$

$$
H_{e}=1-\sum_{i} p i^{2} ; \mathrm{pi}=\text { Frequency opf genetic } \mathrm{i} .
$$

Table 1. RAPD primers used in this study (according to Sahao et al. 2007)

\begin{tabular}{ll}
\hline Primer & Base sequence $\left(\mathbf{5}^{\prime} \rightarrow \mathbf{3}^{\prime}\right)$ \\
\hline OPA 05 & AGGGGTCTTG \\
OPA 07 & GAAACGGGTG \\
OPA 08 & GTGACGTAGG \\
OPA 10 & GTGATCGCAG \\
OPA 11 & CAATCGCCGT \\
OPA 14 & TCTGTGCTGG \\
\hline
\end{tabular}

\section{RESULTS AND DISCUSSION}

\section{Results}

We found 18 genotypes of $R$. mucronata from six locations based on RAPD by using six primers (Table 2). The number of polymorphic bands was 17-22 per primer. OPA-05 produced the fewest polymorphic bands (17 bands), whereas OPA-22 produced the most (22 bands) (Figure 2). The highest percentage of polymorphic bands was obtained with OPA-07 (86.96\%), whereas the lowest was with OPA-05 (73.91\%) (Table 2).

The effectiveness of each primer in detecting polymorphism was evaluated by PIC, EMR, and MI. EMR was used to determine the effective ratio of the number of bands that appeared compared to the number of polymorphic bands. In this study, each primer has an EMR value ranging from 391 to 594 . MI values in each primer ranged between 367.54 and 558.36. All the primers showed the same PIC value but had different EMR and MI values (Table 2). OPA-08 has the highest EMR value and MI value, which means it was the most suitable primer to detect polymorphism in $R$. mucronata.

Cluster analysis placed the $18 R$. mucronata into six groups with a similarity coefficient of 0.24 . The first group includes Oemanu 2, Oemanu 3, and Tanjung Tuamese $(1,2,3)$. The second group contains Tanjung Bastian 3 and Oemanu 1 . The third group includes only Tanjung Bastian 2. The fourth cluster is Humusu $C 2$, Humusu $C 3$, and Tanjung Bastian 1. The fifth group is Humusu $\mathrm{C} 1$ and Abudenok $(1,2,3)$. Finally, the sixth group consists of Kletek $(1,2,3)$ (Figure 3). 
Table 2. Polymorphism and effectivity of RAPD primers used in $R$. mucronata

\begin{tabular}{lccccccc}
\hline Primer & Size range (bp) & TNB & NPB & PB $(\boldsymbol{\%})$ & PIC & EMR & MI \\
\hline OPA-05 & $280-1345$ & 23 & 17 & 73.91 & 0.94 & 391 & 367.54 \\
OPA-07 & $450-1110$ & 23 & 20 & 86.96 & 0.94 & 460 & 432.40 \\
OPA-08 & $270-1315$ & 27 & 22 & 81.48 & 0.94 & 594 & 558.36 \\
OPA-10 & $285-1325$ & 23 & 19 & 82.61 & 0.94 & 437 & 410.78 \\
OPA-11 & $465-1120$ & 22 & 18 & 81.82 & 0.94 & 396 & 372.24 \\
OPA-14 & $375-1030$ & 22 & 18 & 81.82 & 0.94 & 396 & 372.24 \\
Total & & 140 & 114 & 488.6 & 5.64 & 2674 & 2513.56 \\
Mean & & 23.33 & 19 & 81.43 & 0.94 & 445.67 & 418.93 \\
\hline
\end{tabular}

Note: TNB: total number of bands; NPB: number of polymorphic bands; PB (\%): polymorphic band percentage; PIC: polymorphism information content; EMR: effective multiplex ratio; MI: marker index
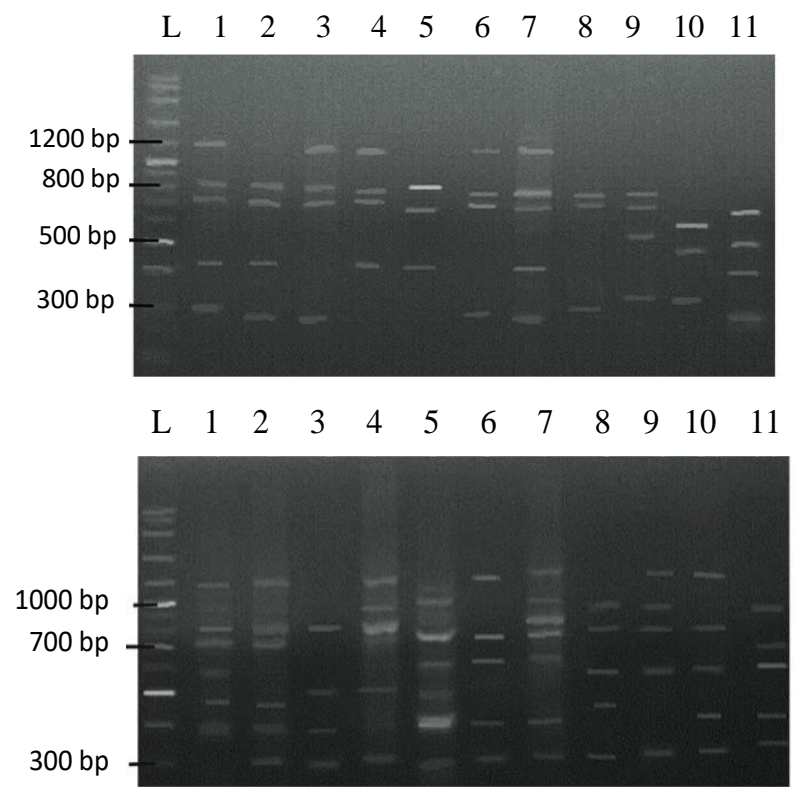

$\begin{array}{llllllll}\mathrm{L} & 12 & 13 & 14 & 15 & 16 & 17 & 18\end{array}$

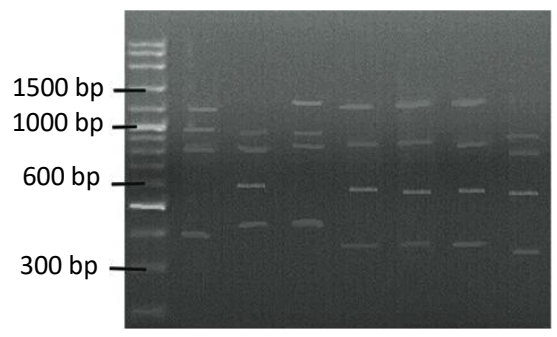

A
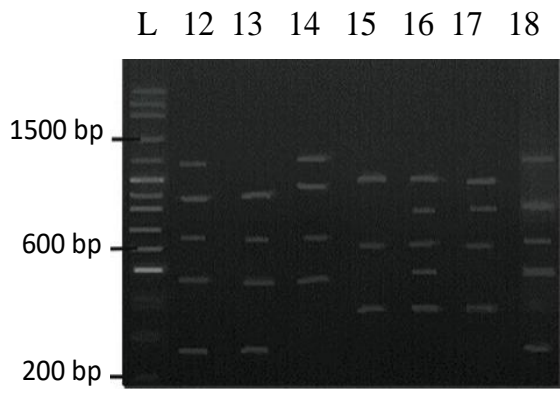

B

Figure 2. DNA profiles showing the most (A. OPA-08) and the fewest (B. OPA-05) polymorphism bands. Note: numbered sequentially, Kletek (1-3), Abudenok (4-6), Humusu C (7-9), Tanjung Bastian (10-12), Oemanu (13-15), Tanjung Tuamese (16-18), DNA Ladder VC 100 bp Plus (L)
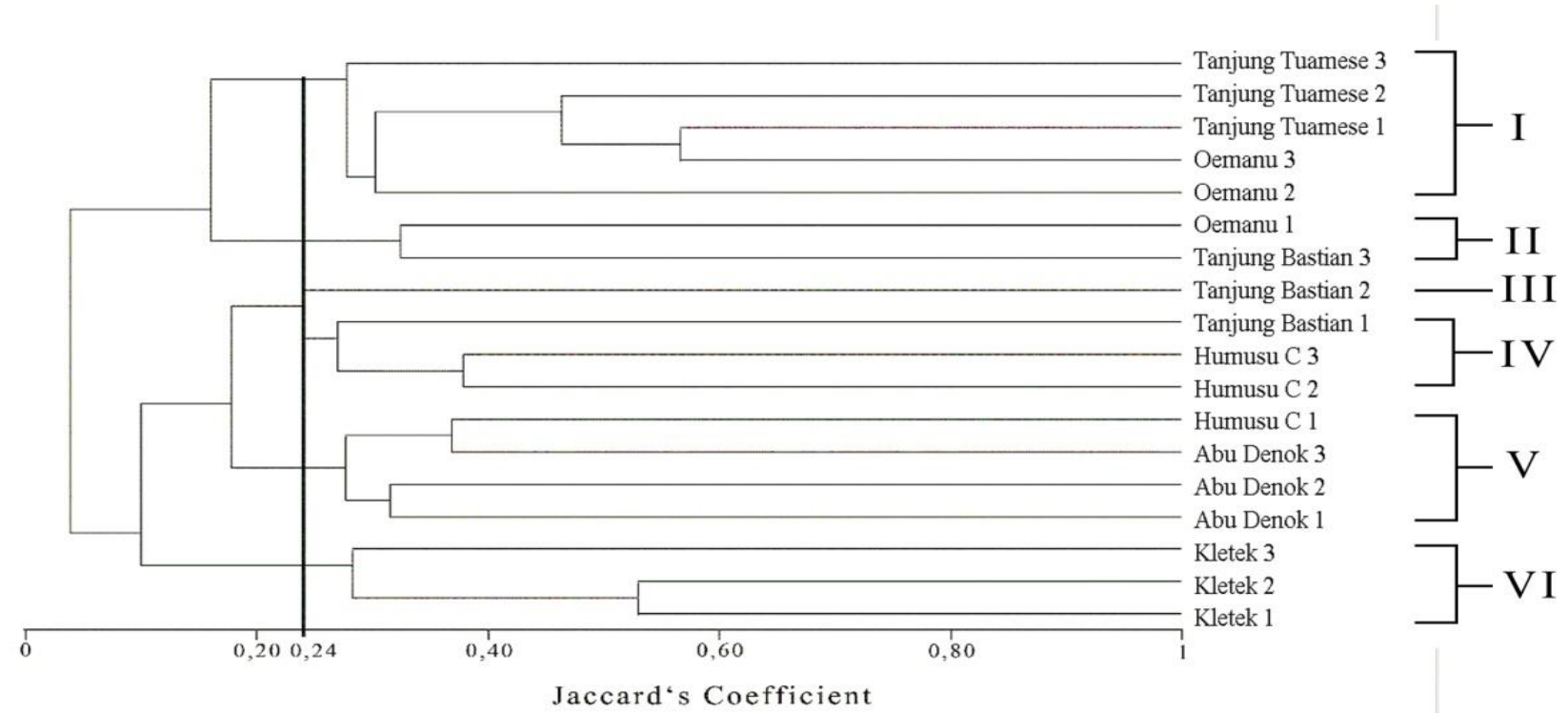

Figure 3. Dendrogram of $18 R$. mucronata samples based on Jaccard's coefficient with the UPGMA method in MVSP software. The number below the dendrogram shows the similarity coefficient value. The number on the right dendrogram shows the cluster 
Table 3. Genetic diversity measurement in six $R$. mucronato mangrove populations on Timor Island, East Nusa Tenggara, Indonesia

\begin{tabular}{lcccc}
\hline \multicolumn{1}{c}{ Population } & $\begin{array}{c}\text { Total } \\
\text { sample }\end{array}$ & $(\mathbf{N a})$ & $(\boldsymbol{N e})$ & $(\boldsymbol{H e})$ \\
\hline Kletek & 3 & 2.993 & 25.333 & 0.666 \\
Abudenok & 3 & 3.000 & 25.000 & 0.667 \\
Humusu C & 3 & 2.997 & 26.000 & 0.666 \\
Tanjung Bastian & 3 & 2.999 & 24.667 & 0.667 \\
Oemanu & 3 & 2.997 & 25.000 & 0.666 \\
Tanjung Tuamese & 3 & 2.974 & 25.333 & 0.664 \\
Total & 18 & 17.960 & 151.333 & 3.996 \\
Mean & & 2.993 & 25.222 & 0.666 \\
\hline
\end{tabular}

Note: Na: number of alleles observed; $N e$ : effective number of alleles; $\mathrm{He}$ : genetic diversity

The genetic diversity of mangrove populations in the northern part of Timor Island was calculated based on the PCR-RAPD band size and the number of bands. Genetic diversity $(\mathrm{He})$ of $R$. mucronata mangrove ranged from 0.664 to 0.667 and can be categorized as moderate.

\section{Discussion \\ Strength of RAPD primer}

All six primers were suitable for use as markers in detecting genetic variations in mangroves because they can produce polymorphic bands. Polymorphic data in RAPD is the result of several events: (i) the insertion of large DNA fragments between the primer attachment sites that exceed the ability of PCR so that no fragments are detected, (ii) small insertions or deletions of DNA strands that cause changes in the size of amplification fragments, (iii) deletion of one of the primer attachment sites resulting in loss of fragments or increased fragment size, and (iv) substitution of one nucleotide in one or two primer target sites that affect the annealing process, which results in the presence or absence of polymorphisms or changes in fragment size (Dar et al. 2017).

DNA polymorphism indicates diversity in the plant genome. The more primers that can amplify polymorphic bands, the greater the diversity in a genome (Mulyaningsih and Indrayani 2014). In contrast to polymorphic bands, there is also a monomorphic band that is thought to encode constitutive properties related to the housekeeping gene. High monomorphic bands indicate narrow genetic diversity (Mulyaningsih and Indrayani 2014).

The most informative primer analysis can be seen from the PIC value (0.94 in this study). PIC is a measure to detect primers that are capable of producing polymorphic bands and refers to the value of a marker to detect polymorphisms in a population. The maximum value of PIC for RAPD markers is 0.5; the higher the PIC value, the better the primer in analyzing genetic variation. PIC is very much influenced by the number of frequencies and allele distribution found (Suryatini 2011).

Each primer used in this study had an EMR value in the range of 391-594. The primers that produced the highest EMR values were OPA-08 with a value of 594, followed by OPA-07 and OPA-10 with EMR values of 460 and 437, respectively. OPA-05 produced the lowest EMR value of 391. EMR analysis is performed to determine the effective ratio of the number of product bands that appear compared to the number of polymorphic bands. The primers that are most effective in producing polymorphic bands on $R$. mucronata mangroves were OPA 7 , OPA 8, OPA 11, and OPA 14.

MI values in each primer ranged from 367.54 to 558.36, OPA 8 has the highest MI value, while OPA 05 has the lowest MI value. The MI value can also be influenced by the total number of the band generated by each primer. In accordance with Kayis et al. (2010), the power of a primer tends to increase with an increasing number of primer bands.

\section{Profile of amplified DNA band}

A total of 140 bands were produced by the primer and varied in intensity. According to Langga et al. (2012), the intensity of DNA bands from amplification by each primer is strongly influenced by the purity and concentration of the printed DNA. The amplified DNA contains compounds such as polysaccharides and phenolic compounds. and a too low concentration of amplified DNA often results in dim or unclear DNA bands. Rahayu and Handayani (2010) stated that the number of bands produced depends on the primer's recognition of the homologous DNA template. The more attachment sites from the primer used. the more DNA bands are produced.

\section{Genetic diversity of $\mathrm{R}$. mucronata mangrove}

Genetic diversity of $R$. mucronata mangroves was determined based on the relationship of genetic similarity between one individual plant and another by comparing DNA banding patterns resulting from PCR amplification. The greater the coefficient of similarity, the higher the genetic similarity between plants; conversely, the smaller the coefficient of similarity between plants, the lower the genetic similarity.

The Jaccard coefficient is used to estimate the level of genetic similarity between individuals (Devy and Hardiyanto. 2017). Based on the similarity matrix (Table 4 ), the $R$. mucronata samples that have the lowest genetic similarity level are samples from Tanjung Bastian 3 and Kletek 3 (0.003). Tanjung Bastian 3 and Humusu C 1 (0.004), and Oemanu 1 and Abudenok 2 (0.006). The Tanjung Tuamese 1 and Oemanu 3 samples have the highest similarity level compared to all $R$. mucronata mangrove samples from other locations (0.567).

These differences can occur as a result of the $R$. mucronata mangrove distribution factor. which is assisted by the flow of seawater when the tides occur. This seawater flow allows the fruits of $R$. mucronata to be carried away by the current and left in a new location. According to Munthali et al. (2013), the seeds of coastal plants are spread by the sea flow, causing these plants to have a wide geographical distribution and resulting in potentially low genetic diversity between populations. The distribution of $R$. mucronata can also be assisted by insects. 
Table 4. Matrix of similarity among group of $R$. mucronata based on UPGMA method according to Jaccard's Coefficient by MVSP software

\begin{tabular}{|c|c|c|c|c|c|c|c|c|c|c|c|c|c|c|c|c|c|c|}
\hline $\begin{array}{l}\text { Sample } \\
\end{array}$ & 1 & 2 & 3 & 4 & 5 & 6 & 7 & 8 & 9 & 10 & 11 & 12 & 13 & 14 & 15 & 16 & 17 & 18 \\
\hline 1 & 1.000 & & & & & & & & & & & & & & & & & \\
\hline 2 & 0.529 & 1.000 & & & & & & & & & & & & & & & & \\
\hline 3 & 0.275 & 0.289 & 1.000 & & & & & & & & & & & & & & & \\
\hline 4 & 0.106 & 0.136 & 0.195 & 1.000 & & & & & & & & & & & & & & \\
\hline 5 & 0.061 & 0.087 & 0.167 & 0.316 & 1.000 & & & & & & & & & & & & & \\
\hline 6 & 0.083 & 0.136 & 0.089 & 0.316 & 0.316 & 1.000 & & & & & & & & & & & & \\
\hline 7 & 0.059 & 0.106 & 0.133 & 0.238 & 0.238 & 0.368 & 1.000 & & & & & & & & & & & \\
\hline 8 & 0.182 & 0.163 & 0.065 & 0.282 & 0.190 & 0.250 & 0.156 & 1.000 & & & & & & & & & & \\
\hline 9 & 0.104 & 0.041 & 0.020 & 0.214 & 0.186 & 0.275 & 0.152 & 0.378 & 1.000 & & & & & & & & & \\
\hline 10 & 0.109 & 0.065 & 0.067 & 0.114 & 0.114 & 0.167 & 0.133 & 0.256 & 0.282 & 1.000 & & & & & & & & \\
\hline 11 & 0.061 & 0.111 & 0.043 & 0.111 & 0.136 & 0.190 & 0.182 & 0.220 & 0.244 & 0.256 & 1.000 & & & & & & & \\
\hline 12 & 0.020 & 0.020 & 0.003 & 0.020 & 0.020 & 0.020 & 0.004 & 0.042 & 0.020 & 0.015 & 0.009 & 1.000 & & & & & & \\
\hline 13 & 0.041 & 0.043 & 0.043 & 0.021 & 0.006 & 0.043 & 0.041 & 0.043 & 0.042 & 0.043 & 0.021 & 0.324 & 1.000 & & & & & \\
\hline 14 & 0.060 & 0.063 & 0.064 & 0.020 & 0.041 & 0.041 & 0.019 & 0.063 & 0.061 & 0.042 & 0.020 & 0.244 & 0.250 & 1.000 & & & & \\
\hline 15 & 0.040 & 0.042 & 0.043 & 0.042 & 0.042 & 0.087 & 0.040 & 0.042 & 0.085 & 0.043 & 0.020 & 0.136 & 0.195 & 0.342 & 1.000 & & & \\
\hline 16 & 0.043 & 0.044 & 0.045 & 0.011 & 0.022 & 0.068 & 0.021 & 0.022 & 0.043 & 0.045 & 0.022 & 0.146 & 0.070 & 0.333 & 0.567 & 1.000 & & \\
\hline 17 & 0.038 & 0.040 & 0.041 & 0.040 & 0.040 & 0.083 & 0.038 & 0.061 & 0.082 & 0.063 & 0.061 & 0.083 & 0.085 & 0.233 & 0.486 & 0.441 & 1.000 & \\
\hline 18 & 0.019 & 0.020 & 0.020 & 0.040 & 0.020 & 0.061 & 0.038 & 0.083 & 0.104 & 0.063 & 0.040 & 0.182 & 0.214 & 0.293 & 0.209 & 0.225 & 0.385 & 1.000 \\
\hline
\end{tabular}

Note: 1. Kletek 1; 2. Kletek 2; 3. Kletek 3; 4. Abudenok 1; 5. Abudenok 2; 6. Abudenok 3; 7. Humusu C 1; 8. Humusu C 2; 9 . Humusu C 3; 10. Tanjung Bastian.1; 11. Tanjung Bastian 2; 12. Tanjung Bastian 3; 13. Oemanu 1; 14. Oemanu 2; 15. Oemanu 3; 16. Tanjung Tuamese 1; 17. Tanjung Tuamese 2; 18. Tanjung Tuamese 3

According to Nurtjahjaningsih et al. (2015), pollen dispersal by insects usually spans a distance of 5-30 meters with frequent pollination times, so pollen is carried away from the same tree. Natural factors are also important in the process of spreading a plant population. Coastal plants are susceptible to disturbance by the physical effects of the environment (exposure to wind, ocean waves, and acidity of seawater) and human activities (wood utilization and land conversion) so that population groups are clustered into fragmented populations with few individuals (Nurtjahjaningsih et al. 2015).

Parameters used to indicate genetic diversity in a population include the number of observed alleles $(\mathrm{Na})$, the number of effective alleles $(\mathrm{Ne})$, and genetic variation $(\mathrm{He})$ (Finkeldey 2005). The results of the analysis showed that the average number of alleles observed in $R$. mucronata populations in Timor Island was 2.993 and the average number of effective alleles was 25.222. The average value of $R$. mucronata genetic diversity on Timor Island was 0.666. Based on the analysis of $R$. mucronata on Timor Island, the population from Abudenok and Tanjung Bastian has the highest diversity value of 0.667 . Meanwhile, the lowest genetic diversity is found in the population of Tanjung Tuamese, with a value of 0.664 . These findings are in accordance with Giang et al. (2006), who stated that the value of genetic diversity of mangrove species is in the range of 0.244 until 0.777 .

Genetic diversity is a level of biodiversity that refers to the total amount of genetic variation in all species found in some or all habitable parts of the earth. Information on genetic diversity is needed to support the conservation and breeding of plants (Ardiyani et al. 2014). Many factors influence the value of genetic diversity. According to Ardiyani et al. (2014), high differentiation among populations and low genetic diversity in the population is due to the dominating self-pollination system compared to cross-pollination or outcrossing. According to Hamrick and Godt (1996), self-pollination can result in low genetic diversity in the population and high genetic differentiation among populations. Hogbin and Peakall (1999) stated that high levels of population differentiation can be caused by several factors, such as crossing systems, genetic drift, demographic fluctuations. or genetic isolation of the population. From the results of this study and referring to Nei (1987), the value of $R$. mucronata genetic diversity on Timor Island was classified as moderate. This result can be used as a reference in $R$. mucronata breeding activities.

\section{Population relationship of $\mathrm{R}$. mucronata}

Kinship is defined as the closeness or genealogical relationship of a species based on phenotypic and genotypic analysis (Arisetianingsih et al. 2010). Relationship analysis using the MVSP program produced a dendrogram as shown in Figure 4. The dendrogram is a grouping based on UPGMA and can indicate the relationship of one plant to another. Wijayanto et al. (2013) stated that the smaller the coefficient of similarity (close to 0 ), the more distant the relationship; conversely, the greater the coefficient of similarity (close to 1). the closer the relationship.

Based on the dendrogram shown in Figure 4, the $R$. mucronata populations have a similarity coefficient of 0.24 or $24 \%$ and correlated with its geographical location. This shows that the closer the geographical distance between $R$. mucronata populations, the closer the genetic distance tends to be. Adjacent populations tend to form a cluster, such as in the first cluster consisting of Oemanu 2, Oemanu 3 , and Tanjung Tuamese $(1,2,3)$; the fifth cluster consisting of Humusu C 1 and Abudenok $(1,2,3)$; and the sixth cluster consisting of Kletek $(1,2,3)$. Nevertheless, 
there are clusters that have different groupings, such as the third cluster which consists only of Tanjung Bastian 2.

Grouping $R$. mucronata from the same population into one sub-group shows that a sub-group is influenced by geographical location. This is presumably because the $R$. mucronata mangrove distribution on Timor Island originated from a common ancestor, thus causing a relationship between individual plants that are relatively near to one another. According to Poerba and Martanti (2008), this tendency is caused by genetic recombination. This is in accordance with Sreekanth et al. (2012), who stated that genetic distance between populations is often associated with geographical distance, although it does not always occur in population genetic studies (Tsuda and Ide 2005). According to Bagindo (2011), the genetic diversity of a population can also occur because of the interaction of several factors, including mutation, migration, recombination, selection, and genetic drift. Mutation, migration, and recombination of genes will enrich diversity in natural populations, while selection and genetic drift will reduce variation.

In conclusion, the genetic diversity among $R$. mucronata in the coastal area of the eastern region of Timor Island was moderate. The population in Abudenok and Tanjung Bastian has the highest genetic diversity with a value of 0.667 , whereas the population of Tanjung Tuamese has the lowest genetic diversity with a value of 0.664 .

\section{ACKNOWLEDGEMENTS}

Our thanks to Ahmad Yani, Vinsensius K. Sabon, Ahmanat Mustafa, Ibnu Rusid, and Maria Fatima Hoar for their assistance in this study. We also express our gratitude to the Indonesian Ministry of Research, Technology and Higher Education for funding this study under scheme Hibah PEKERTI, 2018.

\section{REFERENCES}

Al-Khalifah NS, Shanavaskhan AE. 2017. Molecular identification of date palm cultivars using Random Amplified Polymorphic DNA (RAPD) markers. Methods Mol Biol 1638: 185-196.

Ardiyani M, Sulistyaningsih LD, Esthi YN. 2014. The Genetic Diversity of Tacca leontopetaloides (L.) Kuntze (Taccaceae) from Various Provenances in Indonesia Using Inter Simple Sequence Repeats (ISSR) Markers. Berita Biologi 13 (1): 85-96.

Arif IA, Bakir MA, Khan HA, Al Farhan AH, Al Homaidan AA, Bahkali AH, Al Sadoon M, Shobrak M. 2010. A brief review of molecular techniques to assess plant diversity. Intl J Mol Sci 11 (5): 2079-2096. DOI: 10.3390/ijms11052079

Arisetianingsih RED, Totok ADH, Prakoso B. 2010. Genetic Diversity of Soybean Based on The DNA Pattern of RAPD (Random Amplified Polymorphic DNA). Agrin 14 (1): 37-43.

Bagindo M. 2011. Keragaman Aksesi Pinang (Areca catechu L.) asal Papua, Sulawesi Utara, dan Sumatera Utara berdasarkan Karakter Morfologi dan Penanda RAPD (Random Amplified Polymorphic DNA). [Hon. Thesis]. Departemen Biologi, Fakultas Matematika dan Ilmu Pengetahuan Alam, Institut Pertanian Bogor, Bogor. [Indonesian]

Bessie DM, Schaduw JN, Reppie E, Lasut MT. 2013. Community structure of mangrove at Marine Tourism Park of Kupang Bay, East Nusa Tenggara. J Aquat Sci Manag Spec ed. 1: 3-9.
Darsidi. 1984. Pengelolaan Hutan Mangrove di Indonesia. Prosiding Seminar II Ekosistem Mangrove, Bogor. [Indonesian]

Dar AA, Mudigunda S, Mittal PK, Arumugam N. 2017. Comparative assessment of genetic diversity in Sesamum indicum L. using RAPD and SSR markers. 3 Biotech 7 (1): 10. DOI: 10.1007/s13205-0160578-4

Devy NF, Hardiyanto D. 2017. The Diversity of Gunung Omeh Citrus (Citrus nobilis Lour.) in West Sumatera Based on RAPD Marker. J Hort 27 (2): 155-164.

Sandhya D, Singh S, Chauhan UK, Tiwari MK. 2018. Inter and intraspecific genetic diversity (RAPD) among three most frequent species of macrofungi (Ganoderma lucidum, Leucoagricus sp. and Lentinus sp.) of tropical forest of Central India. J Genet Eng Biotechnol 16 (1): 133-141. DOI: 10.1016/j.jgeb.2017.11.008.

Finkeldey R. 2005. An Introduction To Tropical Forest Genetics Institute of Forest Genetics And Forest Tree Breeding Georg-AugustUniverity, Gottingen.

Giang LH, Geada GL, Hong PN, Tuan MS, Lien NTH, Ikeda S, Harada K. 2006. Genetic variation of two mangrove species in Kandelia (Rhizophoraceae) in Vietnam and surrounding area revealed by microsatellite markers. Intl J Plant Sci 167 (2): 291-298.

Govindaraj M, Vetriventhan M, Srinivasan M. 2015. Importance of genetic diversity assessment in crop plants and its recent advances: an overview of its analytical perspectives. Membrane Water Treatment 8 (5): 449-462. DOI: 10.12989/mwt.2017.8.5.449.

Hamrick JL, MJW Godt. 1996. Effects of life-history traits on genetic diversity in plant species. Phil Trans R Soc Lond B 351: 1291-1298.

Hazarika D, Thangaraj M., Sahu SK, Kathiresan K.. 2013. Genetic diversity in three populations of Avicennia marina along the east coast of India by RAPD markers. J Environ Biol. 34: 663-666.

Hidayatullah M, Umroni A. 2013. Growth of Mangrove (Rhizophora mucronata Lamk) and Productivity of Silvofishery Units at Kupang Regency). Jurnal Penelitian Hutan dan Konservasi Alam 10 (3): 315325.

Hogbin PM, Peakall R. 1999. Evaluation of the contribution of genetic research to the management of the endangered plant Zieria prostata. Conserv Biol 13: 514-522.

Kayis SA, Hakki EE, Pinarkara E. 2010. Comparison of effectiveness of ISSR and RAPD markers in genetic characterization of seized marijuana (Cannabis sativa L.) in Turkey. Afr J Agric Res 5 (21): 2925-2933

Kiran U, Moahnty SK, Roy PS, Behera L, Chand PK. 2015. Genetic diversity among banana cultivars from Odisha using RAPD markers, Sci Res Rep 5 (2): 118-124.

Langga IF, Restu M, Kuswinanti T. 2012. Optimization of temperature and length of incubation in extracting bitti plant (Vitex cofassus Reinw.) DNA and genetic variety analysis with RAPD-PCR. Jurnal Sains \& Teknologi 12 (3): 265-276.

Lira-Medeiros CF, Cardoso MA, Fernandes RA, Ferreira PCG. 2015. Analysis of genetic diversity of two mangrove species with morphological alterations in a natural environment. Diversity 7: 105117.

Manurung J, Siregar IZ, Kusmana C, Dwiyanti FG. 2017. Genetic variation of the mangrove species Avicennia marina in heavy metal polluted estuaries of Cilegon Industrial Area, Indonesia. Biodiversitas 18 (3): 1109-1115.

Matatula J, Poedjirahajoe E, Pudyatmoko S, Sadono R. 2019. Spatial distribution of salinity, mud thickness and slope along mangrove ecosystem of the coast of Kupang District, East Nusa Tenggara, Indonesia. Biodiversitas 20 (6): 1624-1632

Mondini L, Noorani A, Pagnotta MA. 2009. Assessing plant genetic diversity by molecular tools. Diversity 1: 19-25.

Mulyaningsih ES, Indrayani S. 2014. Phenotype and genetic variation for Banten upland rice local cultivars. Jurnal Biologi Indonesia 10 (1): 119-128.

Munthali CRY, Chirwa PW, Changadeya WJ, Akinnifesi FK. 2013. Genetic differentiation and diversity of Adansonia digitata L. (baobab) in Malawi using microsatellite markers. Agrofor Syst 87: $117-130$

Nei M. 1987. Molecular Evolutionary Genetics. Columbia University Press. New York.

Nurtjahjaningsih ILG, Haryanti T, Widyatmoko AYPBC, Indrioko S, Rimbawanto A. 2015. Genetic diversity of Calophyllum inophyllum revealed by RAPD (Random Amplification Polymorphism DNA). Jurnal Pemuliaan Tumbuhan Hutan 9 (2): 91-102. 
Onda Y, Mochida K. 2016. Exploring genetic diversity in plants using high-throughput sequencing techniques. Curr. Genom 17 (4): 358367. DOI: $10.2174 / 1389202917666160331202742$

Poerba YS, Martanti D. 2008. RAPD phenotypic variation of Santalum album L. in Eastern Part of Timor. Biodiversitas 9 (4): 245-249. DOI 10.13057/biodiv/d090401.

Rahayu SE, Handayani S. 2010. Keragaman genetik pandan asal Jawa Barat berdasarkan penanda Inter Simple Sequence Repeat (ISSR). Makara Sains 14 (2): 158-162. [Indonesian]

Romañach SS, DeAngelis DL, Koh HL, Li YH, Teh SY, Raja Barizan RS, Zhai L. 2018. Conservation and restoration of mangroves: Global status, perspectives, and prognosis. Ocean Coast Manag 154: 72-82

Sahao P, Jena S, Mohanty S, Das AB. 2007. Molecular phylogenetic relationship among four species of the mangrove tree genus Bruguiera (Rhizophoeraciae), as revealed by chromosome and RAPD markers. Rev. Biol. Trop. 55 (2): 437-448.

Sambrook J, Russel DW. 2001. Molecular Cloning (A Laboratory Manual). Volume 1, 3rd ed. Cold Spring Harbor Laboratory Press. New York.

Uslan, Pharmawati M. 2015. Optimization of DNA and $\mathrm{MgCl} 2$ Concentrations in Polymerase Chain Reaction-Random Amplified Polymorphic DNA Reaction for Genetic Diversity Analysis of Faloak (Sterculia quadrifida R.Br). Jurnal Bioslogos. 5 (1): 26-34.

Verma KS, ul Haq S, Kachhwaha S, Kothari SL. 2017. RAPD and ISSR marker assessment of genetic diversity in Citrullus colocynthis (L.)
Schrad: a unique source of germplasm highly adapted to drought and high-temperature stress. Biotech 7 (5): 288. DOI: 10.1007/s13205017-0918-z.

Weir BS. 1990. Genetic Data Analysis: Methods for Discrete Genetic Data. Sinauer Associates, Sunderland.

Sudheer DVN, Mastan SG, Rahman H, Reddy MP. 2010. Molecular characterization and genetic diversity analysis of Jatropha curcas L. in India using RAPD and AFLP analysis. Mol Biol Rep 37: 2249-2257.

Sundari ELA, Hakim L, Azrianingsih R, Wahyudi D. 2017. Genetic variability of local durian (Durio zibethinus Murr.) in Ternate Island based on RAPD markers. Plant Cell Biotechnol Mol Biol 18 (1\&2): 68-75.

Suryatini KY. 2011. Analisis keragaman genetik jarak pagar (Jatropha curcas L.) Dengan Metode Inter Simple Sequence Repeats (ISSR). [Thesis]. Program Studi Bioteknologi Pertanian, Program Pascasarjana Universitas Udayana, Denpasar. [Indonesian]

Sreekanth PM, Balasundaran M, Nazeem PA, Suma TB. 2012. Genetic diversity of nine natural Tectona grandis L.f. populations of the Western Ghats in Southern India. Conserv Genet 13: 1409-1419.

Tsuda Y, Ide Y. 2005. Wide-range analysis of genetic structure of Betula maximowicziana, a long-lived pioneer tree species and noble hardwood in the cool temperate zone of Japan. Mol Ecol 14: 9293941 . 